Законность - 2012. - № 10. - С. 3 - 8. 16. Лавров, В. В. Организация межсубъектных взаимоотношений при осуществлении прокурорского надзора за исполнением законов об охране объектов культурного наследия / В. В. Лавров // Криминалистъ. - 2015. - № 2. - С. 39-43.

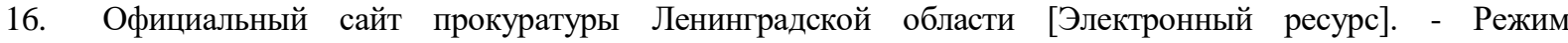
доступа:http://prokuratura-lenobl.ru/news/4139-prokuror-leningradskoy-oblasti-provel-vstrechu-s-

zhurnalistami-po-itogam-nadzorno-profilakticheskih-meropriyatiy-zemlepolzovanie-nasledie-i-finansovyyzaslon-provedennyh-prokuraturoy-oblasti - Дата доступа 21.08.2017

17. Методика и тактика проведения прокурорской проверки / О. Н. Коршунова [и др.]; под ред. О. Н. Коршуновой. -учебное пособие. - СПб., - 2014. - С. 4.

\title{
Кулаков Е.К. \\ Уголовное наказание в виде лишения свободы: проблемные аспекты
}

Санкт-Петербургский государственный экономический университет (Россия, Санкт-Петербург)

doi: $10.18411 / l j-31-01-2018-35$

idsp: 000001:lj-31-01-2018-35

\section{Аннотация}

В статье освящены проблемы, связанные с эффективностью длительности срока лишения свободы, назначаемого в качестве вида уголовного наказания, а также проблемы, связанные с отбыванием наказания в виде лишения свободы больными осужденными, в том числе больных ВИЧ-инфекцией.

В свете настоящих преобразований уголовно-исполнительной системы и гуманизации уголовных наказаний вопрос эффективности длительности сроков лишения свободы становится актуальным и одним из дискуссионных [1, с. 65-66].

Данный вид наказания, как это следует из Уголовного кодекса Российской Федерации (далее УК РФ), наравне с другими видами направлен на достижения целей, закрепленных уголовным законодательством, таких как предупреждение совершения новых преступлений, исправление осужденного лица и восстановление социальной справедливости. В силу чего, при назначении наказания в виде лишения свободы нужно соблюдать баланс поставленных целей и не допускать следования лишь одной из них. К примеру, нередко назначение длительных сроков лишения свободы обосновывается тем, что это позволит оградить общество от лиц, совершивших тяжкие и особо тяжкие преступления и способных повторно совершить преступление, или же будет способствовать устрашению и возмездию, то есть восстановлению социальной справедливости [2, с. 71]. Существуют ситуации, при которых делается приоритет в сторону определенной цели наказания. Между тем проведено достаточное количество исследований, показывающих, что при таком положении цели наказания не достигаются, осужденные лица не исправляются и преступления совершаются вновь. Как пишут авторы, «...в настоящее время, доказано, что существует так называемый эффект решетки, когда слишком длительное пребывание в местах лишения свободы может стимулировать дальнейшую преступную деятельность» [4, с. 319]. А позитивный эффект исправления возможен примерно в первые пять лет отбывания наказания. Иначе говоря, осужденное лицо, в течение долгого времени находится в замкнутом пространстве в обществе людей в определенной степени отклонившихся от социальных норм, и адаптируется к этим условиям жизни. Если в течение пяти лет лицо не поддастся исправлению, то далее в привычной для него среде, попытки его исправления и воспитания окажутся бессмысленны. Осужденный, находящийся в исправительном учреждении, с годами адаптируется к условиям отбывания наказания и к своеобразной микросреде. Ценность «свобода» теряется и становится ненужной, тем самым осужденный перестает воспринимать лишение свободы как наказание. 
Эффективность назначения длительных сроков лишения свободы критикуется и с позиции многих реабилитационных причин. Среди них выделяют: ослабление и даже полная утрата социально полезных связей. Крайне редки случаи, когда лицо, помещенное в исправительное учреждение на длительный период, сохраняло семью, друзей, коллег и прочих знакомых. Как правило, с данными лицами прекращаются даже браки. Не безосновательно в Семейном Кодексе Российской Федерации существует норма, закрепляющая возможность расторжения брака по волеизъявлению одного из супругов, независимо от наличия детей, в ситуации, когда, один из супругов осужден за совершение преступления к лишению свободы на срок свыше трех лет. Кроме того, у лиц, отбывших наказания, возникают проблемы с трудоустройством, жилищными условиями, полностью отсутствием жилья и иными бытовыми трудностями. Указанные факты, безусловно, становятся преградами в процессе социальной адаптации осужденных, и являются катализаторами рецидивной преступности.

Следует обратить внимание на проблему исполнения отбывания уголовных наказаний в виде лишения свободы в отношении ВИЧ-инфицированных осужденных. В настоящее время в пенитенциарных учреждениях России содержится более 49 тысяч ВИЧ-инфицированных, что составляет $11 \%$ от общего числа ВИЧ-инфицированных, официально зарегистрированных в стране. «Факторами, способствующими распространению инфекционных заболеваний среди лиц, содержащихся в местах лишения свободы, становятся также скученность, отсутствие у большинства осужденных элементарных навыков гигиены, высокая подвижность состава осужденных, значительное число представителей групп риска и, конечно же, стресс, вызываемый изоляцией от общества» [3, с. 94], пишет Зернов И.В. На сегодняшний день федеральным законодательством не предусмотрено раздельное содержание ВИЧ-инфицированных и здоровых осужденных в исправительных учреждениях, что существенно осложняет работу по предупреждению совершения правонарушений данной категорией осужденных. Взаимоотношения, которые складываются у здоровых осужденных с ВИЧинфицированными осужденными, часто играют роль неблагоприятного фактора и негативно влияют на отбывание наказания осужденными, дезорганизуют нормальную деятельность исправительного учреждения. А.Д. Никитин полагает, что в ч. 2 ст. 101 Уголовно-исполнительного кодекса Российской Федерации («Медико-санитарное обеспечение осужденных к лишению свободы») необходимо внести изменения, связанные с содержанием ВИЧ-инфицированных осужденных. Это, по его мнению, обусловлено тем, что раздельное содержание ВИЧ- инфицированных и здоровых осужденных позволит снизить уровень распространения ВИЧ-инфекции, а также сократить количество насильственных преступлений, совершаемых в отношении других осужденных и персонала учреждений, обеспечивающих их изоляцию от общества $[5, \mathrm{c}$. 140].

Интересная и проблемная ситуация сложилась сегодня: органы предварительного расследования преступлений и суды стремятся как можно скорее отправить лицо, совершившее преступление, в места лишения свободы, а уголовно-исполнительная система, наоборот, пытается различными способами его досрочно освободить, в том числе по состоянию здоровья. В таком случае смысл наказания в виде лишения свободы в отношении больных осужденных в последние годы постепенно сводится к временной, без качественного исправительного воздействия изоляции от общества, в ходе которой осужденным не создаются условия для улучшения состояния своего здоровья, что приводит к их досрочному освобождению от наказания. А.П. Скиба считает, что «в этом случае деятельность исправительных учреждений ФСИН РФ ориентирована исключительно на преступника, без учета роли потерпевшего от совершения преступления, не позволяет достичь целей уголовно-исполнительного законодательства, повышает уровень рецидивной преступности и заболеваемости населения, а 
устрашительно-исправительный эффект мест лишения свободы постепенно утрачивается по мере увеличения числа судимостей и ухудшения состояния здоровья осужденного» 6 , c. 75]. Также ученый настаивает на разработке новой концепции исполнения лишения свободы в отношении осужденных, имеющих различные заболевания.

Итак, подводя итог исследованию можно заключить, что, во-первых, эффективность длительной изоляции от общества, то есть степень достижения целей наказания и обеспечения тем самым безопасности общества справедливо поддается критики. Наказание в виде лишения свободы на длительные сроки в целом имеет негативное влияние на результат процесса исправления.

Во-вторых, в последнее время правовое регулирование мест отбывания лишения свободы приобрело достаточно высокую значимость благодаря нерешенности некоторых проблем в этой сфере. Помимо указанной сферы вопроса, посвященного отбыванию наказания в виде лишения свободы для больных осужденных, сохраняют свою актуальность и многие другие нерешенные проблемы, связанные как с местами лишения свободы, так и с его регулированием. Тем самым законодателю и правоохранительным органам необходимо сконцентрировать свою деятельность в области закрепления и регулирования мест отбывания наказания в виде лишения свободы.

$$
* * *
$$

1. Дикаев С.У. Концепция развития уголовно-исполнительной системы РФ и проблемы организации отбывания наказания в виде лишения свободы // Криминология: вчера, сегодня, завтра. -2012 . - № 25. - C. 65-70.

2. Дикаев С.У. Цели уголовного наказания и проблемы социальной адаптации лиц, отбывших и отбывающих наказание в виде лишения свободы // Вестник экономики, права и социологии. - 2007. № 2. - С. 70-75.

3. Зернов И.В., Молев Г.И. Места отбывания лишения свободы // Вестник Пензенского государственного университета. - 2015. - № 3 (11). - С. 93 - 98.

4. Каноныхин С.Ю. Возникновение и становление лишения свободы как вида наказания и перспективы его развития // Вестник Тамбовского университета. Серия: Гуманитарные науки. -2010 . - № 12. - С. 318-320.

5. Никитин Д.А. К вопросу о введении специальных условий содержания ВИЧ - инфицированных осужденных / Д.А. Никитин // Человек: преступление и наказание. - 2010. - № 1. - С. 139-142.

6. Скиба А.П. Размышления о смысле наказания в виде лишения свободы в отношении больных осужденных / А.П. Скиба // Юрист-правоведъ. -2007. - № 3. - С. $72-75$.

\section{Лавёрычева С.A. \\ Правовое регулирование реализации права осужденных на свободу вероисповедания}

научный сотрудник НИЦ-1 ФКУ НИИ ФСИН России

(Россия, Москва)

doi: $10.18411 / l j-31-01-2018-36$

idsp: 000001:lj-31-01-2018-36

\section{Аннотация}

В настоящей статье рассмотрены основные правовые акты, регламентирующие реализацию права осужденных на свободу вероисповедания.

Ключевые слова: право осужденного; свобода мысли, совести и
вероисповедания.

Религия в современной жизни занимает одно из важнейших мест. Церковь способствует сохранению традиционных духовных ценностей, оказывает значительное влияние на формирование и развитие национальных интересов России.

Согласно ст. 28 Конституции РФ каждому гарантируется свобода совести и вероисповедания, включая право исповедовать индивидуально или совместно с другими 